\title{
Sistem Informasi Menajemen Aset (Studi Kasus: Desa Barepan)
}

\author{
(Asset Management Information System (Case Study: Barepan Village))
}

\author{
HARIS SETYAWAN, ASRONI
}

\begin{abstract}
Barepan Village is one of the villages in Cawas sub-district, Klaten, Central Java. In 2017 Barepan Village has owned a new building as a means of village administration and obtains assets that support the implementation of government such as computers, tables, chairs, and others. However, asset management is currently not going well and does not have a unique asset database to facilitate the management and tracking of its assets. This caused the difficulty of conducting asset track which made it difficult for asset managers to know the condition of the asset was right, damaged or lost. Therefore, an information system is needed which has the objective to be able to run the business process of asset management to be neat and structured so that asset managers can efficiently manage and track assets. The process of designing an Asset Management Information System using the waterfall model software development method begins with needs analysis, design, coding, testing, and maintenance. From the design stage, it was then created with Code Igniter in the form of a PHP framework with the MVC concept so that a website-based Information System with the MVC concept was produced. Verification and validation are then carried out to determine the suitability of the system design with the Asset Management Information System final results that have been made. Finally, an asset information system can be obtained that fits your needs and archives assets well.
\end{abstract}

Keywords: asset, MVC, PHP, Code Igniter

\section{PENDAHULUAN}

Teknologi komputer yang kian pesat berkembang dan selalu ditopang dengan berbagai macam perangkat lunak atau aplikasi yang juga terus dikembangkan secara luas, membantu pekerjaan manusia menjadi lebih cepat dan akurat sesuai dengan fungsi yang lebih spesifik. Salah satu aplikasi yang saat ini dikembangkan secara leluasa yaitu aplikasi berbasis web.

Aplikasi berbasis web memiliki kelebihan dibanding basis lainnya yaitu memiliki kemampuan untuk di gunakan diseluruh jenis sistem operasi computer dan juga memiliki arsitektur client-server. Kemampuan aplikasi berbasis web tersebut membuka peluang untuk memanfaatkan teknologi web untuk membuat aplikasi yang dapat mengganti pengolahan data dari cara manual beralih menuju komputerisasi.

Sistem informasi merupakan kombinasi dari teknologi informasi dan aktivitas orang yang menggunakan teknologi untuk mendukung operasi dan manajemen. Dalam arti yang sangat luas, istilah sistem informasi yang sering digunakan merujuk kepada interaksi antara orang, proses algoritmik, data, dan teknologi. Dalam pemanfaatannya Sistem Informasi digunakan untuk mengelola suatu proses infromasi dalam suatu lembaga, organisasi ataupun institusi. Kebutuhan efisiesi waktu dan biaya menyebabkan sangat penting menerapkan teknologi dalam sistem informasi. Tak terkecuali sistem informasi pada Desa Barepan. Desa Barepan Klaten Jawa Tengah selaku sebuah institusi pemerintahan tentu memiliki tanggung jawab, salah satunya yakni mengelola aset yang di miliki oleh Desa Barepan. Banyak aset yang di miliki oleh Desa Barepan meliputi aset tanah, gedung, dan barang. Namum dalam proses inventarisasi, pengelola masih menggunakan bantuan Microsoft Excel yang cukup memakan banyak waktu dan tenaga sehingga kurang efektif dan efisien. Banyak data inventaris yang tercecer dan tidak terorganisasi dengan baik. Akibatnya pengelola 
mengalami banyak kesulitan dalam proses penglompokan kategori inventaris, pengecekan keberadaan barang yang tidak pasti dan barang yang telah rusak, pencarian data inventaris menjadi sulit dan memakan banyak waktu, rekapitulasi dan arsip data beresiko terduplikasi, hilang atau rusak, serta proses penyajian laporan yang akan menghabiskan bayak waktu.

Dengan adanya uraian tersebut maka perlu adanya suatu sistem informasi manajemen yang mampu menggantikan cara manual tersebut (Sholikhin and Riasti 2013). Oleh karena itu pada penelitian ini akan dirancang sebuah sistem informasi manajemen berbasis web bernama SIMABAR (Sistem Informasi Manajemen Aset Desa Barepan), yang akan membantu Desa Barepan dalam memanajemen aset/inventaris di Desa Barepan.

Berdasarkan latar belakang yang telah diuraikan, di dapatkan perumusan bahwa manajemen Aset di Desa Barepan masih menggunakan Microsoft Excel, hal ini sangat rentan terhadap human error yang ditemukan dalam proses pengolahan data inventaris. Selanjutnya juga masih mengunakan Microsoft Excel sebagai alat pengelolaan aset/inventaris, proses pencarian data dan juga penyajian laporan aset/inventaris memerlukan banyak waktu atau kurang efisien.

Tujuan dari penelitian ini adalah membangun sistem informasi manajemen aset/ inventaris berbasis web sesuai dengan kebutuhan Desa Barepan, dan membantu dan mempermudah pengelolaan aset/inventaris di Desa Barepan, serta mengurangi resiko yang diakibatkan oleh Human Error pada proses pendataan aset/inventaris di Desa Barepan.

\section{Konsep Dasar Web}

WWW pertama kali ditemukan oleh Tim Berners-Lee pada tahun 1991, WWW (Word Wide Web) atau yang disebut Web adalah suatu layanan di dalam jarigan internet yang berupa ruang informasi(Berners-Lee, Timothy, and Robert 1992). Web terdiri dari jutaan situs web (web site) dan setiap website terdiri banyak halaman web (web page). Halaman-halaman web ini tersebar di seluruh dunia melalui komputer-komputer server yang telah terhubung dengan jaringan internet.

Web server adalah software yang menjadi tulang belakang dari teknologi world wide web yang berfungsi untuk melayani permintaan halaman web. Web server menunggu permintaan dari client yang mengunakan web browser seperti Google Chrome, Netscap Navigator, Internet Explorer, Mozila Firefox, dan program web browser lainnya. Jika permintaan dari pengguna yang mengunakan web browser, maka web server akan memproses permintaan tersebut kemudian memberikan hasil proses berupa data yang di inginkan kembali ke web browser. Cara kerja web server bisa di lihat pada Gambar 1.

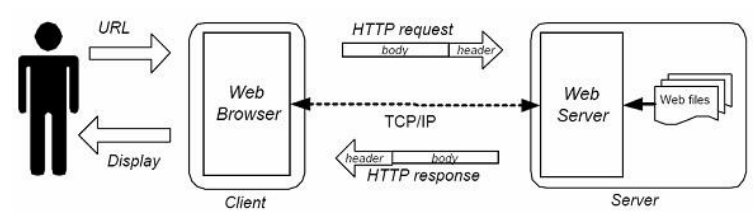

GAMBAR 1. Cara Kerja Web Server

Web browser atau yang disebut juga dengan penjelajah web, adalah sebuah perangkat lunak yang berfungsi menampilkan dan melakukan interaksi dengan dokumen-dokumen yang disediakan oleh web server.

\section{Framework PHP}

Framework dapat diartikan sebagai sebuah kerangka kerja dalam suatu proses. Jika dikaitkan dengan pemrograman PHP maka dapat diartikan sebagai suatu kerangka kerja yang telah terpola dan tersusun yang memudahkan pengembangan web dalam pembuatan web yang menggunakan bahasa pemrograman PHP (Son and Faisal 2017). Dengan kata lain Framework PHP membantu mempromosikan pengembangan aplikasi cepat atau yang disebut Rapid Application Developer (RAD) dan akan menghemat waktu pemrograman dalam membangun aplikasi. Kerangka kerja juga dapat membantu programer untuk membangun aplikasi yang lebih stabil dengan memastikan interaksi database dan coding pada tempat yang terpisah. Hal ini memungkinkan anda untuk menghabiskan banyak waktu menciptakan aplikasi web yang sebenarnya, daripada menghabiskan waktu menulis kode berulang. Gagasan umun di belakang kerangka kerja PHP adalah Model View Controller (MVC).

Model View Controller merupakan suatu konsep rancangan yang sangat popular dalam pembangunan aplikasi perangkat lunak khususnya aplikasi web, MVC memisahkan pengembangan aplikasi berdasarkan komponen utama yang membangun sebuah aplikasi seperti 
manipulasi data, user interface, dan bagian yang menjadi kontrol aplikasi. Arsitektur MVC dapat dilihat pada Gambar 2 (Rick-Anderson n.d.).

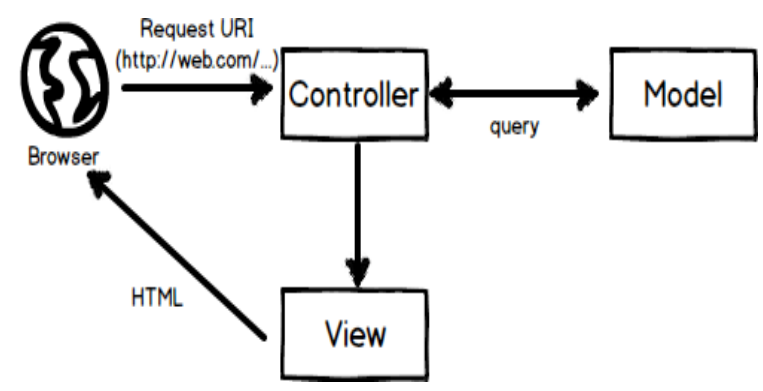

GAMBAR 2. Arsitektu Model View Controller

View, merupakan bagian yang menangani logika presentasi atau desain tampian. Pada suatu aplikasi web bagian ini biasanya berupa berkas template HTML, yang diatur oleh controller. View berfungsi untuk menerima dan mempresentasikan data kepada user. Bagian ini tidak memiliki akses langsung terhadap bagian model.

Model, biasanya berhubungan langsung dengan bagian database untuk manipulasi data, menangani validasi dari bagian controller, namun tidak dapat berhubungan langsung dengan bagian view. Semua skrip dari operasi database seperti skrip SQL akan dituliskan di bagian ini.

Controller, merupakan jembatan antara bagian model dan view, controller berfungsi untuk menerima request data dari user kemudian menentukan apa yang akan diproses oleh aplikasi.

Code Igniter adalah sebuah aplikasi perangkat lunak open source yang berupa framework PHP dengan konsep MVC (Model View Controller). Code Igniter memudahkan pengembang perangkat lunak untuk membuat aplikasi web dengan cepat, mudah dan terstruktur dibandingkan dengan membuatnya dari awal, kelebihan penggunaan Code Igniter dibandingkan framework PHP lainnya adalah karena Code Igniter memiliki konfigurasi yang sangat minim, performa yang cepat, banyaknya komunitas pengembang perangkat lunak yang menggunakan serta dokumentasi penggunaan program yang sangat lengkap dibanding framework PHP lainnya (Panuntun, Rochim, and Martono 2015). Cara Kerja Framework Code Igniter dapat dilihat pada Gambar 3 (Prabowo 2015).

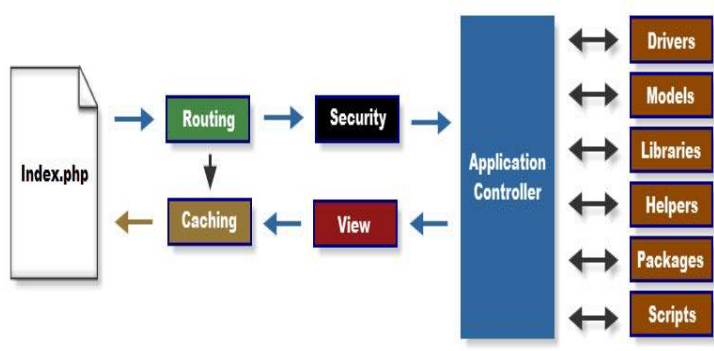

GAMBAR 3. Cara Kerja Framework Code Igniter

Bootstrap merupakan sebuah framework CSS dari twitter, yang menyediakan kumpulan komponen-komponen antar muka dasar pada web yang telah di rancang sedemikian rupa untuk digunakan bersama-sama. Selain komponen anarmuka, Bootstrap juga menyediakan sarana untuk membangun layout halaman dengan mudah dan rapi, serta modifikasi pada tampilan dasar HTML untuk membuat seluruh halaman web yang dikembangkan senada dengan komponenkomponen lainnya (A. Homaidi 2016).

\section{MEtode PENELITIAN}

Dalam penelitian ini, peneliti menggunakan metode pengembangan software model waterfall. Model ini adalah turunan dari metode SDLC (Software Developing Life Cycle) yang mengusung pengembangan perangkat lunak yang sistematis/sekuensial. Pada model waterfall, pengerjaan dari suatu sistem dilakukan secara berurutan atau secara linear.

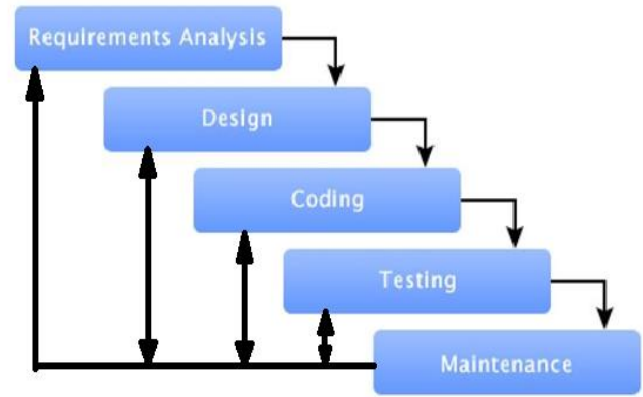

GAMBAR 4. Model Waterfall

Dalam pengembangannya metode waterfall memiliki beberapa tahapan yang berurut yaitu: analisis kebutuhan, desain sistem, pengkodean/implementasi, pengujian, dan pemeliharaan. Tahapan-tahapan dari metode waterfall seperti pada Gambar 4. 


\section{Requirement Analysis}

Langkah ini merupakan analisa terhadap kebutuhan sistem. Pengumpulan data dalam tahap ini bisa melakukan sebuah penelitian, wawancara atau studi literatur. Sistem analis akan menggali informasi sebanyak-banyaknya dari user sehingga akan tercipta sebuah sistem komputer yang bisa melakukan tugas tugas yang diinginkan oleh user tersebut. Tahapan ini akan menghasilkan dokumen user requirement atau bisa dikatakan sebagai data yang berhubungan dengan keinginan user dalam pembuatan sistem. Dokumen inilah yang akan menjadi acuan sistem analis untuk menerjemahkan ke dalam bahasa pemrogram. Requirement analysis yang penulis lakukan ada 2, yaitu:

a. Wawancara: Tujuan dari wawancara adalah untuk mendapatkan informasi yang dibutuhkan dimana sang pewawancara melontarkan pertanyaan-pertanyaan untuk dijawab oleh narasumber.

b. Observasi: Metode observasi ini dilakukan untuk mengamati secara langsung objek penelitian yang bertujuan untuk dapat mengumpulkan data dan menyimpulkan data secara langsung dari lapangan.

\section{System Design}

Tahapan dimana dilakukan penuangan pikiran dan perancangan sistem terhadap solusi dari permasalahan yang ada dengan menggunakan perangkat pemodelan sistem seperti Unified Modeling Language (UML), dan diagram hubungan entitas (entity relationship diagram) serta struktur dan bahasan data.

\section{Implementation (Coding)}

Pada tahap ini desain yang sudah disusun, direalisasikan dengan menulis kode program. Kode program yang dihasilkan masih berupa modul-modul yang selanjutnya akan di integrasikan menjadi sistem yang lengkap untuk meyakinkan bahwa persyaratan perangkat lunak telah dipenuhi. Pembangunan dan implementasi desain sistem dilakukan dengan menggunakan bahasa pemrograman PHP 7 dan CodeIgniter freamwork.

\section{Testing}

Tahapan akhir dimana sistem yang baru diuji kemampuan dan keefektifannya sehingga didapatkan kekurangan dan kelemahan sistem yang kemudian dilakukan pengkajian ulang dan perbaikan terhadap aplikasi menjadi lebih baik dan sempurna. Pengujian sistem yang akan dilakukan pada penelitian ini menggunakan metode tes fungsional yaitu pengujian yang dilakukan dengan mengamati hasil eksekusi melalui data uji dan memeriksa fungsional dari aplikasi.

\section{Maintenance}

Tahap maintenance atau pemeliharaan diperlukan pada saat software selesai dibangun dan diimplementasikan, termasuk didalamnya adalah pengembangan. Pengembangan diperlukan ketika adanya perubahan dari eksternal perusahaan seperti ketika ada pergantian sistem operasi, atau perangkat lainnya. Pada penelitian ini tidak melibatkan maintenance karena proses yang dilakukan hanya sampai pada tahap testing saja.

\section{HASIL DAN PEMBAHASAN}

Hasil dan Pembahasan dilakukan dengan melakukan proses sebagai berikut:

\section{Pengembangan Sistem}

Pada tahap pengembangan sistem, diperoleh informasi mengenai kebutuhan sistem dan bisnis serta daftar komponen dasar dan aplikasi yang sesuai dengan kebutuhan. Identifikasi kebutuhan ini diperlukan untuk menghasilkan spesifikasi kebutuhan sistem yang berisi rincian dari hal-hal yang akan dilakukan sistem ketika dimplementasikan. Pengembangan sistem dimulai dengan analisis kebutuhan dan proses alur sistem, lalu sistem yang sudah dianalisis dicatat atau disusun menjadi rancangan sistem. Rancangan sistem dapat disusun dengan membuat use case diagram, class diagram, dan activity diagram untuk mempermudah proses saat pengembangan(Lesmana, Isnanto, and Widianto 2016). Setelah rancangan sistem telah dibangun maka rancangan database perlu dikembangkan, database ini digunakan sebagai tempat penampungan data dari sistem yang dikembangkan. Perancangan database dapat dicatat di dalam bentuk rancangan Entity Relation Database (ERD) (H. Homaidi, Noviandri, and Purnomo 2017). Rancangan yang perlu dibangun berikutnya dalah rancangan antarmuka atau tampilan aplikasi, rancangan antarmuka dibangun untuk mempermudah proses pembangunan aplikasi (Muhammad, Samopa, and Wibowo 2013). 
Setelah semua rancangan telah selesai disusun maka proses pembangunan aplikasi sudah dapat dilakukan. Bagian pertama yang dikembangkan adalah basis data yang didasarkan pada rancangan Entity Relation Database (ERD). Ketika basis data telah selesai dibangun maka aplikasi sudah siap dikembangkan dengan didasarkan pada rancangan-rancangan sistem yang sudah dibuat sebelumnya.

\section{Pembuatan Basis Data}

Dalam pengembangan website diperlukan sebuah basis data yang digunakan sebagai sumber data untuk kemudian disimpan di dalam server. Server yang digunakan adalah $M y S Q L$ Server. Dalam pembuatan basis data, perangkat lunak pendukung yang digunakan adalah PhpMyAdminn dan MySQL yang terdapat di dalam aplikasi Xampp. Hasil dari pembuatan basis data dalam website dapat dilihat pada Gambar 5.

\section{Implementasi Anatrmuka}

Dalam implementasi, desain antar muka yang sudah dibuat sebelumnya diubah ke dalam bahasa pemrograman yaitu dengan menggunakan bahasa pemrograman PHP dengan metode Codeigniter framework. Perangkat lunak pendukung yang digunakan dalam implementasi aplikasi Xampp yang sudah didalamnya 2 buah server yaitu server aplikasi berupa Apache dan server basis data berupa MySQL. Hasil antarmuka meliputi menu-menu yang terdapat pada Halman Login (Gambar 6), Dashboard (Gambar 10), Master Data (Gambar 8), Transaksi Aset (Gambar 7), dan Laporan (Gambar 9).

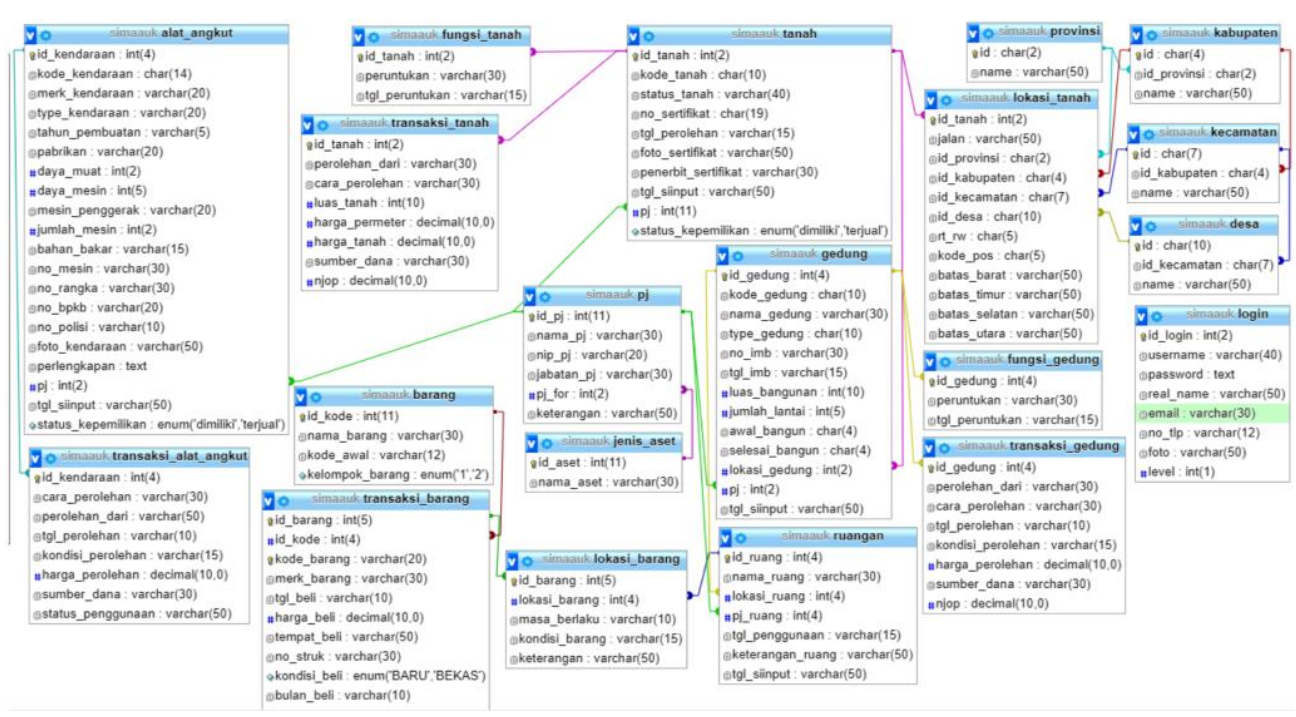

GAMBAR 5. Relasi Antar tabel

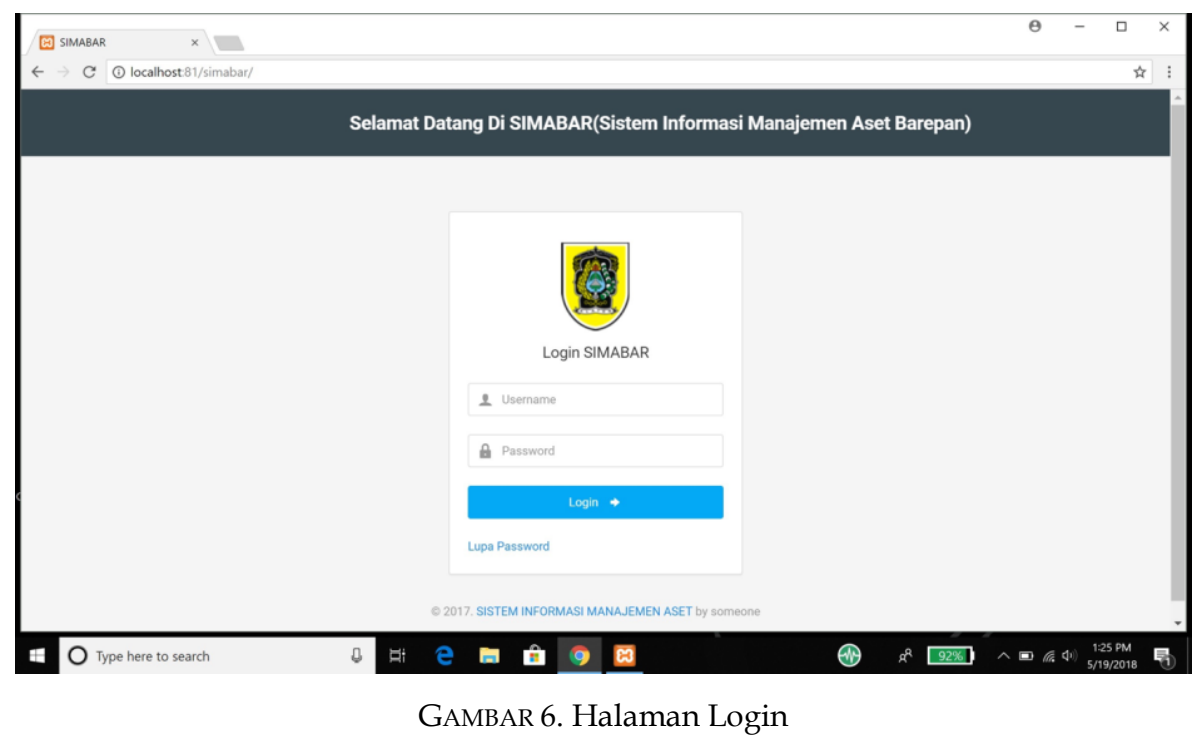



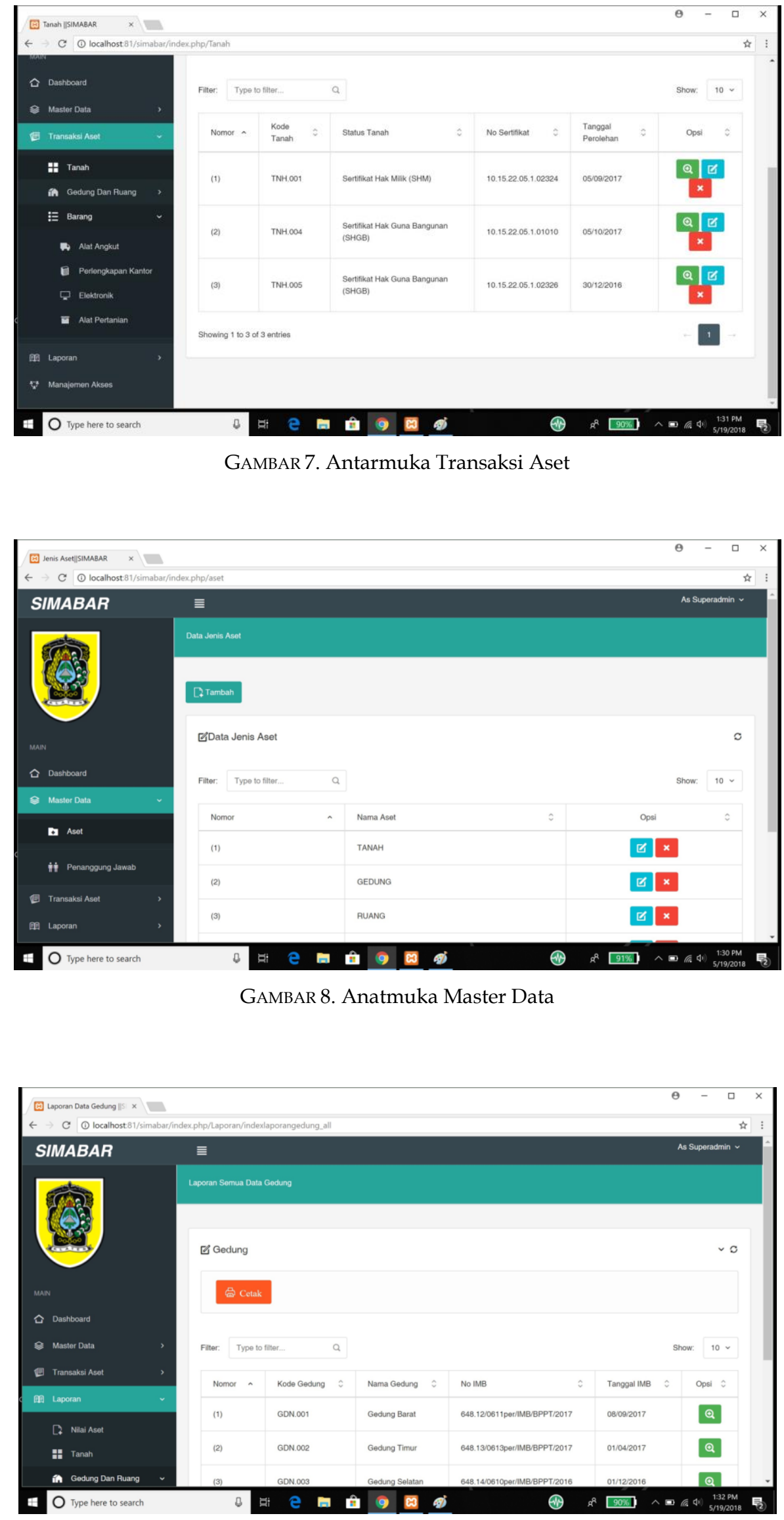

GAMBAR 9. Antarmuka Laporan 


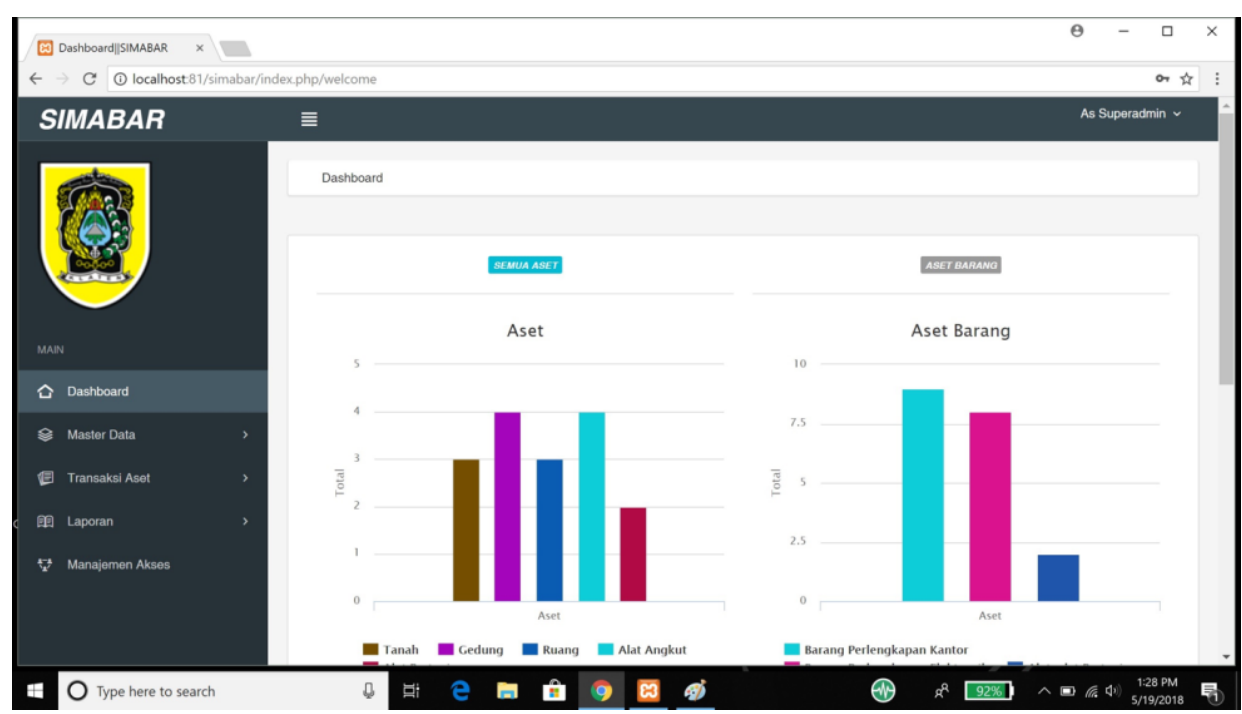

GAMBAR 10. Grafik hubungan antara Total Aset dan Jenis Aset

TABEL 1. Hasil uji antarmuka

\begin{tabular}{cllc}
\hline No. & \multicolumn{1}{c}{ Kasus yang diuji } & \multicolumn{1}{c}{ Test Case } & Status \\
\hline 1 & Halaman Login & Pengguna masuk ke hamalan Dashboard & Berhasil \\
\hline 2 & Menu Dashboard & $\begin{array}{l}\text { Sistem dapat menmpilkan halaman } \\
\text { Dashboard }\end{array}$ & Berhasil \\
\hline 3 & Menu Master Aset & $\begin{array}{l}\text { Sistem dapat menampilkan halaman } \\
\text { Master Data }\end{array}$ & Berhasil \\
\hline 4 & Menu Transaksi Aset & $\begin{array}{l}\text { Sistem dapat menampilkan halaman } \\
\text { Transaksi Aset }\end{array}$ & Berhasil \\
\hline 5 & Menu Laporan & Sistem dapat menampilkan halaman & Baporan \\
\hline
\end{tabular}

\section{Blackbox testing}

Pada Tabel 1. Menunjukkan hasil pengujian dengan blackbox dimana pengujian difokuskan pada keperluan fungsional untuk penegmbangan software untuk menemukan kesalahan dengan beberapa kategori sebagai berikut: Kesalahan Anatarmuka, Fungsional yang salah atau hilang, Kesalahan basis data baika berupa struktur atau pengaksesan, Kesalahan Unjuk Kerja, Kesalahan terminasi dan inisialisasi (Mustaqbal, Firdaus, and Rahmadi 2016). Dari hasil pengujian didapatkan hasil yang baik dengan status "Berhasil", ini berarti sistem informasi sudah siap diimplementasikan dan layak uji.

\section{KESIMPULAN}

Berdasarkan tahapan-tahapan yang telah dilalui pada Persiapan, Perencanaan, Desain, Implementasi dan Pengujian, maka kesimpulan yang dapat diambil dari penelitian adalah sebagai berikut:

a. Aplikasi Sistem Informasi Manajemen Aset/inventaris telah berhasil dibangun.

b. Aplikasi manajemen aset/inventaris ini telah sesuai dengan kebutuhan pengelola aset/inventaris sehingga pengelola aset/inventaris tidak perlu menggunakan Microsoft Excel sebagai alat pengeolaan aset/inventaris.

c. Sistem Informasi Manajemen Aset/inventaris dapat menampilkan dan mencetak data aset.

\section{UCAPAN TERIMA KASIH}

Ucapan terimaksih untuk Fakultas Teknik Universitas Muhammadiyah Yogyakarta yang telah memberikan dukungan dan Pihak Pemerintahan Desa Barepan, Cawas, Klaten Jawa Tengah yang telah memebrikan kesempatan untuk menerapakan sistem informasi aset. 


\section{DAFTAR PUSTAKA}

Berners-Lee, J. Timothy, and Cailliau Robert. (1992). "World-Wide Web: The Information Universe | Internet Research | Vol 2, No 1.” 1992. https://www.emeraldinsight.com/doi/ab s/10.1108/eb047254.

Homaidi, Ahmad. (2016). "Sistem Informasi Akademik Amik Ibrahimy Berbasis Web." Sistem Informasi Akademik AMIK Ibrahimy Berbasis Web. 2016. http://www.ejournal.amiki.ac.id/index.p $\mathrm{hp} / \mathrm{JIMI} /$ article/view/5/3.

Homaidi, Heru, Achmad Munawir Noviandri, and Yuda Ed Purnomo. (2017). "Penerapan Sistem Informasi Berbasis Komputer Untuk Pengelolaan Aset Bagi SMP Muhammadiyah 1 Kartasura." Penerapan Sistem Informasi Berbasis Komputer Untuk Pengelolaan Aset Bagi SMP Muhammadiyah 1 Kartasura. 2017. http://journal.ummgl.ac.id/index.php/ur ecol/article/view/1159/681.

Lesmana, Hendy Cahya, Rizal Isnanto, and Eko Didik Widianto. (2016). "Perancangan Aplikasi 'Sholat Yukk' Pada Android Sebagai Media Pembelajaran Ibadah Shalat Anak-Anak." Jurnal Teknologi dan Sistem Komputer 4 (4): 502-9.

Muhammad, Noval Aditya, Febriliyan Samopa, and Radityo Prasetianto Wibowo. (2013). "Pembuatan Aplikasi Presensi Perkuliahan Berbasis Fingerprint (Studi Kasus: Jurusan Sistem Informasi Institut Teknologi Sepuluh Nopember Surabaya)." Jurnal Teknik ITS 2 (3): A465-69.

https://doi.org/10.12962/j23373539.v2i 3.5160 .

Mustaqbal, M. Sidi, Roeri Fajri Firdaus, and Hendra Rahmadi. (2016). "Pengujian Aplikasi Menggunakan Black Box Testing Boundary Value Analysis (Studi Kasus: Aplikasi Prediksi Kelulusan Smnptn)." Jurnal Ilmiah Teknologi Informasi Terapan 1 (3). http://jitter.widyatama.ac.id/index.php/j itter/article/view/70.
Panuntun, Rizal, Adian Fatchur Rochim, and Kurniawan Teguh Martono. (2015). "Perancangan Papan Informasi Digital Berbasis Web pada Raspberry pi." Jurnal Teknologi dan Sistem Komputer 3 (2): 192-97.

Prabowo, Donni. (2015). "Website ECommerce Menggunakan Model View Controller ( Mvc ) Dengan Framework Codeigniter Studi Kasus: Toko Miniatur" 16 (1): 7.

Rick-Anderson. (n.d). "Getting Started with ASP.NET MVC 5." Accessed July 31, 2018. https://docs.microsoft.com/enus/aspnet/mvc/overview/gettingstarted/introduction/getting-started.

Sholikhin, Akhmad, and Berliana Kusuma Riasti. (2013). "Pembangunan Sistem Informasi Inventarisasi Sekolah Pada Dinas Pendidikan Kabupaten Rembang Berbasis Web." IJNS - Indonesian Journal on Networking and Security 2 (2). https://doi.org/10.1123/ijns.v2i2.93.

Son, Harison, and Roby Faisal. (2017). "Aplikasi Penilaian Kinerja Dosen pada Proses Belajar Mengajar Berbasis Web: Studi Kasus di Badan Penjamin Mutu Internal Institut Teknologi Padang." Jurnal Teknologi dan Sistem Komputer 5 (2): 89-93.

PENULIS:

Haris Setyawan

Program Studi Teknik Informatika, Fakultas Teknik, Universitas Muhammadiyah Yogyakarta, Yogyakarta

Email: haris.setyawan@umy.ac.id

Asroni

Proram Studi Teknik Informatika, Fakultas Teknik, Universitas Muhammadiyah Yogyakarta, Yogyakarta

Email: asroni@umy.ac.id 